\title{
Inclusion of Different Level of Khesari for Promotion in Broiler
}

\author{
Md. H. Azad ${ }^{1 *}$, M. R. Tiwari ${ }^{2}$, N. R. Poudel ${ }^{2}$, B.M. Shah ${ }^{2,}$ B.K. J.C ${ }^{2}$ and G.P. Chaudhary ${ }^{2}$ \\ ${ }^{1}$ Animal Nutrition Division, Khumaltar, Lalitpur \\ ${ }^{2}$ Regional Agricultural Research Station, Parwanipur, Bara \\ *Corresponding author: azardhusneid@hotmail.com
}

\begin{abstract}
An experiment was conducted at Regional Agricultural Research Station, Parwanipur, Bara for 38 days to test the effect of Khesari leaves inclusion in broiler feed and its effect on growth performance. Altogether 135 day-olds Cobb-500 broiler birds were procured from Shivam Hatchery, Birgung and divided into 3 treatments with 3 replications $(15$ birds in each replication) by using completely randomized design. Concentrate feed was purchased from Posak Feed industry, Birgung. Control group (T1) was fed without inclusion of Khesari leaves and whereas T2 and T3 groups were fed $5 \%$ and $10 \%$ Khesari leaves added feed respectively. Diet replaced with $5 \%$ and $10 \%$ Khesari leaves were offered from $14^{\text {th }}$ day of trial to T2 and T3 broilers group respectively. Experimental birds were provided adlib amount of grower feed (B1) for 21 days and that after finisher feed (B3) for 21 days and had easily access to drinking water. Feed intake was recorded daily and body weight gain was measured in 7 days interval. Experiment revealed that highest weight gain was observed in $T 3$ (2.55 kg) followed by T1 (2.48) where inclusion of $10 \%$ Khesari leaves and normal feed respectively, which was also significant among diet groups. Similarly, highest cumulative feed intake was also observed for T3 (4.23 kg) followed by $T 1(3.90 \mathrm{~kg})$ which was also significant among diet groups. Experiment suggested that further study should be carried out to precise the appropriate level of organic acids inclusion and higher cost benefit ratio.
\end{abstract}

Keywords: Broiler, Growth performance, Lathyrus sativus

\section{INTRODUCTION}

Agriculture is the major sector of Nepalese economy. Therefore, the development of agriculture sector is key for the development of national economy. Livestock, including poultry is an integral part of the agricultural part of the agricultural production system in Nepal, providing manure and high value animal protein such as meat and eggs for the human consumption. Agricultural production is the main product and more than $65 \%$ of the population depends upon agriculture. Contribution of agricultural sector in Gross Domestic product (GDP) of Nepal is $33 \%$. Among them contribution of livestock sector in total GDP is $26.8 \%$ and poultry sub sector within livestock contributes $8 \%$ of Agriculture Gross Domestic product (AGDP) and Indigenous poultry is widely prevalent which contributes $55 \%$ of total poultry population (MOAD,2015). A Nepali eats $4.1 \mathrm{~kg}$ per chicken and 44 eggs annually, well below the global average, according to a recent survey report titled "Nepal Commercial Poultry Survey 2014-15" (CBS, 2016). The global average chicken meat consumption is $12 \mathrm{~kg}$ per person, while average per capita egg 
consumption is 153 units annually, according to the Food and Agriculture Organization of the United Nations.

The high price of feed cost in poultry could be controlled by replacing with forage diets like Khesari leaves. Broiler diet replaced with forage might reduce the feed cost of broiler that definitely enhances the productivity of the poultry farming. Feed cost occupies $70 \%$ of broiler farming. Therefore, forage inclusion in feed reduces its cost. In many areas, feed savings are typically greatest in the late spring and early fall, when lush pasture provides plenty of highquality forages to offset a significant amount of the cost of feeding poultry. Additionally, insect and other invertebrate populations (poultry favourites) in the pasture are booming at the same time. The use of different forage materials for like Khesari (Lathyrus sativus) organic poultry could support the principle of increasing utilisation of local resources which could have positive effects on the cycling of nutrients in the system. Grass pea (Lathyrus sativus) is a dual- purpose annual legume grown for its seeds for human consumption, and fodder for livestock feeding. Grass pea is one of the preferred legume seeds in low fertility soils and arid areas because of its outstanding tolerance of dry or flooding conditions Forage materials grown on farm utilise nitrogen $(\mathrm{N})$ and phosphorus $(\mathrm{P})$ from the soil. Therefore, foraging behavior can reduce the accumulation of $\mathrm{N}$ and $\mathrm{P}$ in the soil and hence ensure a desirable balance of $\mathrm{N}$ and $\mathrm{P}$ in a natural ecosystem which subsequently will protect the environment from acidification and global warming (Dekker et. al., 2012). Forage materials have welfare benefits in terms of reduced feather pecking and other undesirable behavior (Van Krimpen et. al., 2005). However, little attention has been paid to consider the nutrients of forage materials to facilitate the transition to $100 \%$ organic feed supply within the stipulated time.

Lathyrus sativus (Khesari), also known as grass pea, blue sweet pea, chickling pea, chickling vetch, Indian pea, white pea and white vetch, is a legume (family Fabaceae). It is a particularly important crop in areas that are prone to drought and famine, and is thought of as an 'insurance crop' as it produces reliable yields when all other crops fail. The seeds contain a neurotoxin that causes a neuro-degenerative disease when the seeds are consumed as a primary protein source for a prolonged period.Lathyrus sativus grows best where the average temperature is $10-25^{\circ} \mathrm{C}$ and average rainfall is $400-650 \mathrm{~mm}$ (16-26 in) per year. Like other legumes, it improves the nitrogen content of soil. The crop can survive drought or floods but grows best in moist soils. It tolerates a range of soil types from light sandy through loamy to heavy clay, and acid, neutral, or alkaline soils. It does not tolerate shade. 


\section{MATERIALS AND METHODS}

Experimental Birds: The experiment was carried out on Cobb 500 broiler chickens at Regional Agricultural Research Station, Parwanipur, Bara from 24 December 2019 to 7 February for 38 days. 135 days-old birds were procured from Shivam hatchery, Birgung, Parsa and were allotted into three treatments with three replications having 15 birds in each replication by using Complete Randomized Design (CRD). All experimental birds were vaccinated with F1 vaccine (a) one drop /bird against Ranikhet at the first week. The vaccination schedule was followed as referred by broiler vaccination protocol.

Diet Composition: The control group (T1) was normal diet without inclusion of Khesari leaves whereas T2 and T3 groups diet were prepared by inclusion 5\% and 10\% KKhesari leaves, respectively.

Chemical Analysis:Representative samples were analyzed for Dry Matter (DM), crude Protein $(\mathrm{CP})$, crude Fibre $(\mathrm{CF})$, organic matter $(\mathrm{OM})$ and ash contents $(\mathrm{TA})$. The DM was determined by oven drying at $100^{\circ} \mathrm{C}$ for $24 \mathrm{hrs}$. Crude protein of the samples was determined using the Kjeldahl method. Ash content was determined by ashing at $550^{\circ} \mathrm{C}$ in a muffle furnace for $16 \mathrm{hrs}$ (AOAC, 1980). Crude Ether of the samples was determined using the Van Soest method (Goering, H.K. and Van Soest 1970).

Experimental Diet: The following experimental diet was provided to the birds (Table 1).

Table 1: Experimental diet

\begin{tabular}{|c|l|}
\hline Treatment & \multicolumn{1}{|c|}{ Diet } \\
\hline 1 & Adlib concentrate mixture (without inclusion of Khesari leaves) \\
\hline 2 & Adlib concentrate mixture (inclusion 5\% Khesari leaves in diet) \\
\hline 3 & Adlib concentrate mixture (inclusion 10\% Khesari leaves in diet) \\
\hline
\end{tabular}

Feeding Regime: Concentrate mixture was given on group basis and was provided to the experimental birds twice a day (morning and evening) in adlib amount for both periods (starter-21 days and finisher - 21 days) of the experiment. Drinking water was provided in adequate amount. Diet replaced with $5 \%$ and $10 \%$ Khesari leaves were offered from $14^{\text {th }}$ day of trial to $\mathrm{T} 2$ and $\mathrm{T} 3$ broilers group respectively.

Data Measurement: The trial period consisted for 38 days (21 days starter and 17 days finisher). Quantity of concentrate mixture given daily to the birds in groups weighed daily and refusal was weighed in the next morning. The body weight gain was measured in group basis (replication-wise) in seven days interval in the morning before feeding. 


\section{RESULT AND DISCUSSION}

\section{Chemical Composition of Concentrate Mixture}

The chemical composition of treated and non-treated concentrate mixture is given in Table 2 .

Table 2: Chemical composition of the compound feed (on DM basis)

\begin{tabular}{|l|c|c|c|c|c|}
\hline Concentrate mixture & DM & TA & OM & CP & CF \\
\hline Feed (Starter) & 90.47 & 6.15 & 93.85 & 22.16 & 3.69 \\
\hline Feed (Finisher) & 88.60 & 4.58 & 95.42 & 19.37 & 4.28 \\
\hline Khesari Leaves & 21.7 & 10.5 & 69.4 & 24.2 & 25.8 \\
\hline
\end{tabular}

\section{Data Analysis}

Data of feed intake and body weight gain were analyzed by "One-way ANOVA" test for every measurement using statistical package Minitab 2003, versions 13.20.

\section{Cumulative Feed Intake}

The average feed intake of experimental bird is presented in Table (3). Mean feed intake of experimental birds was recorded 40.82gmin 7 days which reached $184.04 \mathrm{gm}$ at the end of experiment ( 38 days which was significant among diet groups. At the 7 days of experiment, feed intake of T1, T2 and T3 was noted (42, 38.88 and $41.60 \mathrm{gm}$, respectively). By the 28 days of experiment, highest feed intake was recorded for T3 (170.80 gm) followed by T1 (153.78 gm). Similarly, at the 35 days of experiment, feed intake was higher in T3 group (186.40 gm) followed by T1 (174.49 gm). Finally, at the 38 days of experiment, feed intake was higher in T3 group (198.40 gm) followed by T1 (185.24 gm).The cumulative feed intake of the experiment (2019) highest cumulative feed intake was for T3 (4232.711 gm) followed by T1 (3909.46 gm) and T2 (3793.68 gm) respectively. There was non-significant effect in feed intake for 7 days and 14 days whereas there was significant effect in feed intake during 21, 28, 35 and 38 days during entire experimental period between treatment groups. 
Table 3: Feed intake of the experimental bird /day, g (Mean \pm SD)

\begin{tabular}{|c|c|c|c|c|c|c|c|}
\hline TRT & \multicolumn{6}{|c|}{ Days } & \multirow{2}{*}{$\begin{array}{l}\text { Cumulative } \\
\text { Feed intake }\end{array}$} \\
\hline & 7 & 14 & 21 & 28 & 35 & 38 & \\
\hline 1 & $42.0 \pm 3.05$ & $77.51 \pm 1.88$ & $119.73 \pm 6.1$ & $153.78 \pm 6.6$ & $174.49 \pm 3.0$ & $185.24 \pm 4.2$ & 3909.47 \\
\hline 2 & $38.88 \pm 1.01$ & $77.60 \pm 2.55$ & $121.07 \pm 1.66$ & $152.04 \pm 4.5$ & $169.69 \pm 2.16$ & $168.89 \pm 1.8$ & 3793.69 \\
\hline 3 & $41.60 \pm 2.27$ & $78.53 \pm 1.33$ & $134.71 \pm 5.09$ & $170.80 \pm 1.4$ & $186.40 \pm 8.9$ & $198.00 \pm 0.66$ & 4232.71 \\
\hline Mean & $40.82 \pm 2.45$ & $77.88 \pm 1.66$ & $125.17 \pm 8.25$ & $158.87 \pm 9.8$ & $176.86 \pm 8.89$ & $184.04 \pm 12.8$ & 3978.62 \\
\hline $\begin{array}{c}\mathrm{P} \\
\text { value }\end{array}$ & $\mathrm{P}>0.05$ & $\mathrm{P}>0.05$ & $\mathrm{P}<0.05$ & $\mathrm{P}<0.05$ & $\mathrm{P}<0.05$ & $\mathrm{P}<0.05$ & $\mathrm{P}<0.05$ \\
\hline
\end{tabular}

Body Weight Gain: The body weight gain trend of experimental birds is given in Table 4 and Figure 1.

Table 4: Body weight gain trend of experimental birds, g (Mean \pm SD)

\begin{tabular}{|c|c|c|c|c|c|c|c|c|c|c|}
\hline TRT & 0 days & 7 days & 14 days & 21 days & 28 days & 35 days & 38 days & $\begin{array}{c}\text { Total } \\
\text { weight } \\
\text { gain }(\mathrm{gm})\end{array}$ & $\begin{array}{c}\text { Average wt } \\
\text { gain (gm) }\end{array}$ & $\begin{array}{l}\mathrm{C} \\
\mathrm{R}\end{array}$ \\
\hline $\mathrm{T} 1$ & $\begin{array}{c}45.37 \pm \\
2.87\end{array}$ & $\begin{array}{c}155.2 \pm 13.2 \\
9\end{array}$ & $364.8 \pm 8.3$ & $829.3 \pm 31.41$ & $1446.4 \pm 59.2$ & $2203.1 \pm 49.9$ & $2532 \pm 45.1$ & 2486.63 & 65.43 & 1.57 \\
\hline T2 & $43.28 \pm 0.33$ & $151.0 \pm 2.1$ & $364.4 \pm 8.4$ & $801.4 \pm 23.8$ & $1382.1 \pm 35.6$ & $2126.2 \pm 58.0$ & $2468.5 \pm 47.8$ & 2425.22 & 63.82 & 1.56 \\
\hline T3 & $46.0 \pm 2.69$ & $164.6 \pm 4.05$ & $380.6 \pm 12.6$ & $841.3 \pm 19.1$ & $1459.8 \pm 11.4$ & $2243.4 \pm 65.4$ & $2605.4 \pm 20.6$ & 2559.4 & 67.35 & 1.65 \\
\hline Mean & $44.53 \pm 2.21$ & $156.9 \pm 9.28$ & $370.0 \pm 11.81$ & $824.0 \pm 28.20$ & $1429.5 \pm 50.2$ & $2190.9 \pm 72.09$ & $2535.3 \pm 68.6$ & 2490.77 & 65.52 & 1.59 \\
\hline P value & $\mathrm{P}>0.05$ & $\mathrm{P}>0.05$ & $\mathrm{P}>0.05$ & $\mathrm{P}>0.05$ & $\mathrm{P}>0.05$ & $\mathrm{P}>0.05$ & $\mathrm{P}<0.05$ & $\mathrm{P}<0.05$ & $\mathrm{P}<0.05$ & $\mathrm{P}<0.05$ \\
\hline
\end{tabular}

Average mean body weight of experimental birds was $44.53 \mathrm{gm}$ at the beginning which reached $2490.77 \mathrm{~g}$ by the end of experiment. At the 7 days of experiment, highest body weight gain was noted for T3 (164.6 gm) followed by T1 (155.22 gm). During 14 days of experiment, higher body weight gain was found in T3 (380.6 gm) followed by T1 (364.89 gm). Similarly, at 21 days of experiment, higher body weight gain was found in T3 (841.3 gm) followed by T1 (829.33 gm). At the 28 days of experiment, higher body weight gain was observed in T3 group (1459.8 
gm) followed by T1 (1446.4 gm). During 35 days of experiment, higher body weight gain was observed in T3 group (2243.4 gm) followed by T1 (2203.1 gm). Finally, at 38 days of experiment, higher body weight gain was observed in T3 group (2605.4 gm) followed by T1 (2532.0 gm). Experiment revealed that highest weight gain was observed in T3 $(2.5 \mathrm{~kg})$ followed by T1 (2.4) where diets were replaced by $10 \%$ Khesari leaves and normal diet without inclusion of Khesari leaves respectively. There was significant effect at total body weight gain. Similarly, least FCR was recorded for T3 group (1.65) followed by T1 (1.57) and T2 (1.56) respectively. There was significant effect in diet on body weight gain and FCR.

Table 5: Non-edible carcass weight of experimental birds, g (mean \pm SD)

\begin{tabular}{|l|l|l|l|l|l|l|l|l|}
\hline Treatment & $\begin{array}{l}\text { Head } \\
\text { Wt }\end{array}$ & $\begin{array}{l}\text { Feet } \\
\text { Wt (2) }\end{array}$ & $\begin{array}{l}\text { Giblet Wt } \\
\text { (heart, } \\
\text { gizzard, } \\
\text { liver etc.) }\end{array}$ & $\begin{array}{l}\text { Croup, } \\
\text { Intestines } \\
\text { Wt }\end{array}$ & $\begin{array}{l}\text { Live } \\
\text { Wt }\end{array}$ & Skin wt & $\begin{array}{l}\text { Abdominal } \\
\text { Fat }\end{array}$ & Blood \\
\hline 1 & 63 & 74 & 132 & 126 & 2532 & 145 & 39 & 72 \\
\hline 2 & 60 & 68 & 138 & 139 & 2468 & 158 & 42 & 77 \\
\hline 3 & 68 & 90 & 158 & 188 & 2605 & 170 & 43 & 75 \\
\hline Mean & 63.5 & 77.3 & 136.67 & 151.0 & 2535.0 & 157.67 & 41.11 & 74.66 \\
& \pm 3.67 & \pm 9.8 & \pm 3.80 & \pm 28.3 & \pm 59.3 & \pm 10.8 & \pm 2.0 & \pm 2.34 \\
\hline P-value & $\mathrm{P}<0.05$ & $\mathrm{P}<0.05$ & $\mathrm{P}<0.05$ & $\mathrm{P}<0.05$ & $\mathrm{P}<0.05$ & $\mathrm{P}<0.05$ & $\mathrm{P}<0.05$ & $\mathrm{P}<0.05$ \\
\hline
\end{tabular}

Average mean head weight of experimental birds was $63.5 \mathrm{gm}$, highest head weight was noted for T3 $(68 \mathrm{gm})$ followed by T1 (63 gm). The average feet weight of broiler was $77.3 \mathrm{gm}$, highest feet weight gain was noted for T3 $(90 \mathrm{gm})$ followed by T1 (74 gm). Similarly, the average giblet weight was $136.67 \mathrm{gm}$, highest giblet weight gain was noted for T3 (158 gm) followed by T2 (138) g. The average croup, intestines weight was $151.0 \mathrm{gm}$, highest croup, intestine was noted for T3 (188 gm) followed by T2 (139 gm). The average skin weight of experimental birds were $157.67 \mathrm{gm}$, highest skin weight was noted for T3 (170 gm) followed by T2 (158 gm). The average abdominal fat of broiler was $41.11 \mathrm{gm}$, highest abdominal fat weight gain was noted for T3 (43 gm) followed by T2 (42 gm). Finally, the average blood collected during slaughtering of broiler was $84.66 \mathrm{gm}$, highest blood collection was noted for T2 $(87 \mathrm{gm})$ followed by T3 $(85 \mathrm{gm})$. A significant difference was observed between non-edible carcasses between the treatment groups.

Table 6: Cut parts weight of experimental birds, $g$ (mean \pm SD)

\begin{tabular}{|l|l|l|l|l|l|}
\hline Treatment & $\begin{array}{l}\text { Thigh } \\
\text { wt }\end{array}$ & $\begin{array}{l}\text { Back } \\
\text { Wt }\end{array}$ & $\begin{array}{l}\text { Neck } \\
\text { Wt }\end{array}$ & $\begin{array}{l}\text { Wings } \\
\text { Wt }\end{array}$ & $\begin{array}{l}\text { Breast } \\
\text { Wt }\end{array}$ \\
\hline 1 & 321 & 280 & 53 & 130 & 610 \\
\hline 2 & 314 & 286 & 57 & 126 & 632 \\
\hline 3 & 500 & 380 & 59 & 164 & 712 \\
\hline Mean & $373.00 \pm 95.33$ & $320.00 \pm 45.14$ & $56.33 \pm 2.91$ & $141.67 \pm 17.2$ & $564.33 \pm 110.8$ \\
\hline P-value & $\mathrm{P}<0.05$ & $\mathrm{P}<0.05$ & $\mathrm{P}<0.05$ & $\mathrm{P}<0.05$ & $\mathrm{P}<0.05$ \\
\hline
\end{tabular}


Average mean thigh weight of experimental birds was $373 \mathrm{gm}$, highest thigh weight was noted for T3 (500 gm) followed by T1 (321 gm). Average mean back weight of experimental birds was 320 gm, highest back weight was noted for T3 (380 gm) followed by T2 (286 gm). Average mean neck weight of experimental birds was $56.33 \mathrm{gm}$, highest neck weight was noted for T3 (59 gm) followed by T2 (59 gm). Average mean wings weight of experimental birds was 141.67 gm, highest wing weight was noted for T3 (164 gm) followed by T1 (130 gm). Average mean breast weight of experimental birds was $564.33 \mathrm{gm}$, highest breast weight was noted for T3 (712 gm) followed by T2 (632 gm). A significant difference was observed in cut parts of birds among the treatment groups.

Table 7: Dressing \% of experimental birds, g (Mean \pm SD)

\begin{tabular}{|c|c|}
\hline Treatment & Dressing \% \\
\hline 1 & 73.14 \\
\hline 2 & 77.22 \\
\hline 3 & 69.5 \\
\hline Mean & 73.28 \\
\hline
\end{tabular}

The mean dressing percentage of experimental birds was noted $73.28 \%$, highest dressing $\%$ was noted in T2 (77.22\%) followed by T1 $(73.14 \%)$. The dressing percentage of T1, T2 and T3 were $68.96 \%, 73.14 \%, 77.22 \%$ and $69.5 \%$ respectively.

\section{DISCUSSION}

This experiment was initiated with aim to increase productivity of broiler with the reduction of their feed cost. The mean cumulative feed intake of bird per day was noted $3978.62 \mathrm{gm}$ and it was highest (4232.71 gm) for T3 lowest (3909.46 gm) in T1. There was significant effect in feed intake during entire experimental period between 21, 28, 35 and 38 days between treatment groups. Similarly, mean FCR was noted 1.59 and was highest in T3 (1.65) lowest in T2 (1.56 $\mathrm{kg}$ ). Likewise, mean total weight gain was $2535.3 \mathrm{gm}$ and it was higher for T3 (2605.4 gm) and lowest in T2 $(2468.8$ gm). There was significantly difference $(\mathrm{P}<0.05)$ in total weight gain and average weight gain of experiment. The total weight gain and average weight gain was lower in T2 due to low intake of diet in comparison to other treatment groups. Average mean head weight of experimental birds was $63.5 \mathrm{gm}$, highest head weight was noted for T3 (68 gm) followed by T1 (63 gm). The average feet weight of broiler was $77.3 \mathrm{gm}$, highest feet weight gain was noted for T3 $(90 \mathrm{gm})$ followed by T1 $(74 \mathrm{gm})$. The dressing percentage of T1, T2 and T3 were $68.96 \%$, $73.14 \%, 77.22 \%$ and $69.5 \%$ respectively.

Latif et al. (1975) conducted a trial where he reared for 14 day in battery brooders, that were given diets containing 100, 222 or $367 \mathrm{~g} / \mathrm{kg}$ of Khesari meal (Lathyrus sativus) in three different experiments. When Khesari was either autoclaved or heated in a commercial "micronisation" process and then incorporated at $367 \mathrm{~g} / \mathrm{kg}$ in a balanced chick diet, growth and efficiency of food utilisation were at least equal to those obtained with a maize-soya diet. Chicken provide a readily available, high-quality and inexpensive source of proteins, vitamins, and micronutrients accepted by all ethnic groups. Village also increases food security for vulnerable families. Economically, 
village can provide a ready source of cash. Feedstuff is an aspect of high economic importance in the rearing of commercial poultry not only because it is primarily responsible for the growth response of birds, but mainly because it represents the largest cost in the production cycle (Avila et.al., 1992). For instance, the broilers' energy requirements are responsible for $70 \%$ of the cost of the ration (Skinner et.al., 1992) and, besides, the processing method and the grain type interfere differently on the economic viability and animal performance.

Forages can provide a significant amount of poultry nutrition, reducing the amount of feed that a poultry farmer feeds a flock. Although poultry are not ruminants - they're monogastric - a good pasture is still a valuable resource for the flock. In many areas, feed savings are typically greatest in the late spring and early fall, when lush pasture provides plenty of high-quality forages to offset a significant amount of the cost of feeding poultry. Khesari plants are available in all region of Nepal. They could be cultivated easily in every regions of Nepal. Therefore, plant leaves are used in this poultry trial being low toxic comparision to its seed. Although the general opinion of poultry producers and feed manufacturers is that the fibre content of the rations should be kept below 7\%. The fibre content in Khesari plant is found to be $25 \%$ approximately.

Therefore, in this experiment Khesari leaves are included in small amount (5\% and 10\%) for the treatment groups. The feed cost of broiler could be reduced by the inclusion of feed by Khesari leaves. Farmers are not aware about the various types of improved management practices, the development of new technologies. In other words, the farmers themselves are practising traditional farming system. This might lead to production but only it meets the farmers' basic needs. There is lack of technical knowledge on production, processing and slaughtering of poultry.

\section{CONCLUSION}

Khesari (Lathyrus sativus) leaves can be included in poultry diet for reducing feed cost and as a growth promoter. It has resulted better growth performance. However, further study should be conducted to ascertain the optimum level of inclusion and duration of experiment to get more benefit from broiler production. The expensive feed cost could be reduced by the addition of Khesari leaves in the poultry diets.

\section{ACKNOWLEDGEMENT}

The authors would like to express their most sincere gratitude and appreciation to NARC for funding this research. Similarly, supportive role of Director (MrTufelAftar) of Agricultural Regional Research Station deserves high appreciation without that conduction of experiment was impossible. Mr. Basanta Kumar Shrestha (Technical Officer) and his teams, Animal Nutrition Division, Khumaltar also deserve appreciation for their dedicated work in chemical analysis of feed ingredients. 


\section{REFERENCES}

AOAC (1980). Official methods of analysis. Association of Official Analysis Chemists, Washington DC, U.S.A.

A. Latif, M and R. Morris and T. (1976). Use of Khesari (Lathyrus sativus) in Chick Diets. British Poultry Science 17. 539-546.

Avila V.S., F Jaenisch, L.C. Pieniz, M.C Ledur, L Albino and P.A.V. Oliveira (1992). Production and management of broiler. Embrapa Pigs and birds, 1992.

Castell, A. G., R. L Cliplef, C.J. Briggs, C.G. Campbell, and J.E. Bruni (1994). Evaluation of Lathyrus (Lathyrus sativus L.) as in ingredient in pig starter and grower diets. Canada Journal of Animal Science., 74 (3): 529-539.

Dekker, S.E.M., A.J.A.Aarnik, I.J.M. De boer, and G.T. Koerkamp (2012). Total loss and distribution of nitrogen and phosphorus in the outdoor run of organic laying hens. British Poultry Science, 53:731-740.

Hanbury, C. D.C.L. White, B.P Mullan, K. H. M, Siddique (2000). A review of the potential of Lathyrus sativus L. and L. cicera L. grain for use as animal feed. Animal Feed Science Technology., 87 (1/2): 1-27.

Horsted, K., M. Hammershoj, and J.E. Hermansen (2007). Short-term effects on productivity and egg quality in nutrient-restricted versus non-restricted organic layers with access to different forage crops. Acta Agriculturae Scandinavica, Section A. Animal Science, 56:42-54.

Jeff, M. (2002). The poultry site. Poultry news health welfare diseases, markets and economics $5 \mathrm{~m}$ publishing benchmark and smithy wood drive Sheffield,S35 1 QN, England.

Krimpen, M.M.,T.M. Van, S.M. Borgijink, D Schokker, S.A Vastenhouw, F.T. Bree, J.M.G. Rebel, , M.A. Smits, and R.A. Emous (2016). Effects of rye inclusion in diets on broiler performance, gut morphology and microbiota composition, 16th International Conference on Production Diseases in Farm Animals, Wageningen, 201606-22/2016-06-23).

Low, R. K.C, R.G. Rotter, R.R. Marquardt and C.G. Campbell (1990). Use of Lathyrus sativus L. (var. Seminisalbi) as a foodstuff for poultry. Broiler Poultry Science., 31 (3): 615-625

Ministry of Livestock Development (2016). Organization Structure. Present Condition and commitment.

Skinner, J.T., A.L. Waldroup and P.W. Waldroup (1992). Effects of dietary nutrient density on performance and carcass quality of broilers 42 to 49 days of age. The Journal of Applied Poultry Research 1992; 1: 367-372.

Statistical Information on Nepalese Agriculture (2015). Ministry of Agriculture and Cooperatives. MOAC, Nepal.

Steenfeldt, S., S. Afrose, M. Hammershoj and K. Horsted (2013). How to safeguard adequate nutrition in organic poultry production. Proceedings of the 19th European Symposium on Poultry Nutrition, s. 60-66.

Svihus, B. (2011). The gizzard: Function, influence of diet structure and effects on nutrient availability. World's Poultry Science Journal. 67:207-224.

VAN Krimpen., M.M., R.P. Kwakkel, B.F.J. Reuvekamp, C.M.C. Vander, L.A. Denhartog and M.W.A. Verstegen (2005). Impact of feeding management on feather pecking in laying hens. Worlds Poultry Science Journal, 61: 663-685 